\title{
A LIBERDADE HUMANA E O PROBLEMA DO MAL: O PENSAMENTO TRÁGICO DE DOSTOIÉVSKI
}

\author{
THE HUMAN FREEDOM AND THE PROBLEM OF EVIL: THE TRAGIC THOUGHT OF \\ DOSTOYEVSKY
}

Carlos Antônio de Sousa Coutinho*

\begin{abstract}
RESUMO
Um particular e relevante capítulo da filosofia contemporânea é, sem sobra de dúvidas, o da história das interpretações filosóficas das obras do romancista russo Fiódor Dostoiévski. A presente pesquisa desenvolve uma investigação sobre algumas das ideias filosóficas fundamentais presentes nos romances do escritor russo como relevantes paradigmas interpretativos do pensamento filosófico contemporâneo a partir do século XX. Para alcançar tal escopo propõe-se uma leitura dialética de algumas das suas principais obras, entendida no sentido de fazer irromper no horizonte da filosofia e da antropologia as muitas e decisivas questões que os personagens dostoievskianos põem a si mesmos e uns aos outros, indagando qual seja a sua ideia sobre o homem, sobre a liberdade e sobre o mal, tendo como fio condutor de toda a investigação a sua concepção de "pensamento trágico". Considera-se assim a possibilidade de que a filosofia possa também "habitar" espaços diferentes daqueles "canonicamente" delimitados.
\end{abstract}

PALAVRAS-CHAVE: Dostoiévski. Liberdade. Mal. Antropologia. Pensamento Trágico.

\begin{abstract}
A particular and important chapter in contemporary philosophy is, beyond doubt, the history of philosophical interpretations of the works of Russian novelist Fyodor Dostoyevsky. This research develops an investigation into some of the fundamental philosophical ideas present in the Russian writer novels as relevant interpretive paradigms of contemporary philosophical thought from the 20th century. To achieve this scope proposes a dialectical reading of some of his major works, understood as to break the horizon of philosophy and anthropology the many critical issues that Dostoyevskyan characters put themselves and each other, wondering which is your idea about man, about freedom and about evil, with the common thread of all research his conception of "tragic thought." So it is considered the possibility that philosophy can also "inhabit" different spaces of those "canonically" delimited.
\end{abstract}

KEYSWORD: Dostoyevsky. Freedom. Evil. Anthropology. Tragic Thought.

\footnotetext{
* Mestre em Filosofia pela Pontificia Università San Tommaso D’Aquino - ANGELICUM, de Roma - Itália (2008). Professor dos cursos de Bacharelado em Filosofia, Teologia e Direito da Faculdade Católica Rainha do Sertão - FCRS, de Quixadá/CE, desde 2008. E-mail: carloscoutinho@fcrs.edu.br
} 


\section{Introdução}

Um particular e relevante capítulo da filosofia contemporânea é, sem sobra de dúvidas, o da história das interpretações filosóficas das obras do romancista russo Fiódor Mikháilovitch Dostoiévski (Moscou, 30/10/1821 - São Petersburgo, 28/01/1881). Relacionamos aqui apenas alguns dos nomes mais importantes que desenharam este cenário interpretativo: Nikolai Berdiaev, Viatcheslav Ivanov, Paul Evdokimov, Vladimir Soloviov, Lev Shestov, Friedrich Nietzsche, Sigmund Freud, Albert Camus, Hermann Hesse, Romano Guardini, Thomas Mann, Henri de Lubac, Luigi Pareyson, René Girard, Sergio Givone, Luiz Felipe Pondé (no Brasil), entre outros.

Propomo-nos a realizar uma investigação sobre algumas das ideias filosóficas fundamentais presentes nos romances do referido escritor russo a partir de chaves de leitura fornecidas por alguns dos seus principais intérpretes, como relevantes paradigmas interpretativos do pensamento filosófico contemporâneo a partir do século XX. Para alcançar tal escopo, não faremos uma leitura de caráter analítico da obra dostoievskiana, ou seja, uma espécie de crítica literária pura e simplesmente, mas ao invés uma leitura dialética, entendida no sentido de fazer irromper no horizonte da filosofia e da antropologia algumas das muitas e decisivas questões que os personagens dostoievskianos põem a si mesmos e uns aos outros num jogo dialético. Posto isso, considera-se assim a possibilidade de que a filosofia possa também "habitar" espaços diferentes daqueles "canonicamente" delimitados pela tradição.

Nikolai Berdiaev, filósofo russo, destaca a importância da filosofia na obra dostoievskiana:

\footnotetext{
Ele foi um verdadeiro filósofo, o maior filósofo russo. Deu muitíssimo à filosofia. O pensamento filosófico deveria ser impregnado de suas concepções. A obra de Dostoiévski é importantíssima para a antropologia filosófica, para a filosofia da história, para a filosofia da religião, para a filosofia moral. Ele talvez tenha aprendido pouco da filosofia, mas muito pode ensiná-la, e nós já há algum tempo filosofamos sobre as coisas últimas sob a guia de Dostoiévski. (BERDJAEV, 2002, p.23, tradução nossa).
}

O intuito aqui não é certamente aquele de extrapolar dos romances de Dostoiévski um sistema de pensamento bem definido, que a propósito não existe e nem poderia ser deduzido sem evidentes distorções. Não é o pensamento desencarnado que nos interessa, mas o pensamento encarnado nos personagens dos seus romances, pois é aos personagens que é necessário indagar qual seja a sua ideia sobre o homem, sobre a liberdade, sobre o mal. De 
modo que um traço fundamental de seus romances-tragédias é o fato de que seus personagens não transmitem meras opiniões, mas ao contrário personificam ideias, "encarnam" ideias, como ressalta Luigi Pareyson ao afirmar que "os romances de Dostoiéviski são, pois, colocações de problemas e contrastes de ideias e os seus heróis são, verdadeira e propriamente ideias personificadas" (PAREYSON, 2012, p.36). Ainda segundo Pareyson, "para Dostoiévski, um homem é uma verdadeira personalidade enquanto acolhe no seu íntimo uma ideia e vive no mistério desta. As personalidades são ideias encarnadas" (PAREYSON, 2012, p.37). Disso se pode depreender que Dostoiévski é um verdadeiro antropólogo cuja antropologia, como veremos, referenda, em certa medida, uma visão cristã do homem:

\begin{abstract}
Dostoiévski teve um só pensamento dominante, somente um problema ao qual dedicou todos os seus esforços criativos. Este problema é o homem e o seu destino [...] Resolver o problema do homem significa resolver o problema de Deus. Toda a obra de Dostoiévski é uma defesa do homem e do seu destino, levada até a impiedade, mas que se resolve com o confiar o destino do homem ao Deus-homem, Cristo (BERDJAEV, 2002, p.27, tradução nossa).
\end{abstract}

Antes, porém, é preciso ressaltar que se existe passagem de uma dimensão literária a uma dimensão especulativa, esta acontece sob o sinal do pensamento trágico, pensamento que não dissolve as contradições, mas as assume reconhecendo que contraditória é a própria realidade. Assim, na cadência dos diálogos e nas trocas de ideias entre os seus personagens Dostoiévski permite-nos vislumbrar a sua concepção sobre a vida humana, uma concepção radicalmente centrada nas ideias de liberdade e dignidade.

Assumindo a perspectiva segundo a qual a concepção dostoievskiana está impregnada de filosofia numa percepção religiosa da existência humana, pode-se dizer que seus personagens representam as consequências que a tragicidade inerente à liberdade humana pode acarretar ao indivíduo, colocando-se numa direção oposta àquela dos grandes pensadores místicos cristãos. A sua visão é uma intuição cristã do mundo e da existência humana que gira em torno da sacralidade da vida, uma sacralidade que não pode ter outra motivação que não derive necessariamente da sua origem divina, como destaca Berdiaev:

Dostoiévski é atormentado pelo mistério do espírito humano. Preocupa ao seu pensamento a antropologia, não a teologia. Não como pagão, não como homem natural resolve o problema de Deus, mas como cristão, como homem espiritual resolve o problema do homem. Na verdade, o problema de Deus é um problema humano. O problema do homem é um problema divino, e, talvez, o mistério divino se revela melhor através do mistério humano do que com uma busca de Deus através da natureza e fora do homem (BERDJAEV, 2002, p.14-15, tradução nossa). 
O homem é livre, tragicamente livre, nos diz Dostoiévski, porque foi criado à imagem e semelhança de Deus que o colocou no mundo dotado de razão, faculdade que deve saber canalizar para poder colher ao longo de sua existência a diferença entre o bem e o mal. Dostoiévski conduz o homem pelas vias extremas do arbítrio e da revolta para revelar que no arbítrio se destrói a liberdade e que na revolta se nega o homem. E para redimir um mundo tão sombrio e dar um sentido e uma nobreza a uma reafirmação do livre-arbítrio, seria necessária uma fé; e de fato cada página dos romances dostoievskianos transparece essa aspiração não expressa, essa inderrogável exigência do espírito humano.

Fio condutor de toda a exposição é a concepção dostoievskiana de "pensamento trágico" que, longe de estéreis definições pessimistas ou otimistas, afirma que à base da condição humana existe apenas a livre e consciente escolha do homem que tragicamente pode fazer, com a mesma força - ou seja, a liberdade - tanto o bem quanto o mal, que a felicidade não se possa alcançar a não ser por meio da dor, e que o único meio para se combater o mal seja o sofrimento.

Poucos souberam tratar temas tão elevados e profundos com tanta força e clareza expressiva como fizera Dostoievski. Luiz Felipe Pondé ilustra bem esse aspecto:

\begin{abstract}
Trata-se, na realidade, de uma filosofia da desgraça. Esta nos falará da falência do ser humano (profetismo agressivo), de sua disfunção necessária (antropologia cética), de sua insuficiência (sua sobrenaturalidade esquecida e sua disjunção miserável como sintoma desse esquecimento, isto é, seu exílio na natureza), do conflito polifônico infinito (drama multivocal como categoria essencial para descrever a condição humana que fala de si mesma), consequências, todas, do distanciamento de Deus (PONDÉ, 2013, p.19).
\end{abstract}

Apresentadas essas premissas gerais, chamamos em causa a filosofia a fim de questionar e propor algumas ideias tomadas dos romances de Dostoiévski para a construção de uma reflexão de natureza antropológica, pois é o próprio escritor, definitivamente, que nos oferece o ponto de partida, a orientação e os instrumentos para a nossa investigação.

\title{
2 A concepção de homem
}

As intuições de Dostoiévski não estão condensadas num sistema abstrato de ideias; ao que parece, não se pode pretender de um artista tal sistema. Por outro lado não é absolutamente insustentável afirmar que em seus romances estão presentes ideias fundamentais ligadas ao destino do homem, do mundo e de Deus. Todavia, é o homem que 
constitui o centro de gravitação do seu pensamento. Para Dostoiévski o homem não é apenas um ser psicológico, mas também espiritual. Em seus romances exprime o dinamismo e o turbilhão apaixonado da natureza humana. É verdade que são intuições artísticas, mas não no sentido comum do termo. A sua arte é quase profética, marcada por um pensamento trágico, conforme aponta Pondé:

\begin{abstract}
A antropologia de Dostoiévski seria a antropologia de um homem inacabado, e inacabado por ser um animal do infinito. Mas, depois da queda, esse infinito é vivido como uma espécie de inferno constante, cuja imagem projetada no espelho noético é o niilismo. É preciso considerar isso com bastante calma para que fique claro - e é algo que torna Dostoiévski fascinante - que, ao mesmo tempo em que o infinito pós-queda é um inferno, só existe salvação ao atravessá-lo (PONDÉ, 2013, p.179-180).
\end{abstract}

Nos romances de Dostoievski, somos atingidos pelo contraste de duas forças, e desse conflito nasce a grandeza artística e profética do autor. A primeira força é o desespero, a aceitação do mal, o sofrimento como um inferno que deve ser atravessado para que então a luz redentora dissipe as trevas da angústia. Essa luz, de acordo com o autor russo, é a luz de Cristo que refulge também nos abismos mais profundos das trevas, e este é, por assim dizer, o caminho por excelência do Cristianismo. O que queremos dizer é bem ilustrado por Berdiaev quando afirma que "Dostoiévski nos arrasta em um abismo obscuro, que se escancara ao interno da natureza humana. Conduz-nos para as trevas infernais. Mas também naquelas trevas deve resplandecer a luz. Ele quer conquistar a luz a partir das trevas" (BERDJAEV, 2002, p.32, tradução nossa). A segunda força, aquela verdadeiramente sobre-humana desse autor, nos indica um elemento diverso da morte, uma outra realidade, uma essência diferente. É a consciência do homem. Mesmo que toda a vida humana seja guerra e dor, baixeza e atrocidade, existe sempre algo mais: a consciência. É verdade que a consciência também nos conduz através da dor e do terror da morte, nos conduz à miséria e à culpa, mas também nos faz sair da insuportável solidão do absurdo, nos coloca em contato com o sentido das coisas, com a sua essência, com a eternidade. Contudo, para o romancista russo, a consciência não tem relação com a moral ou a lei, antes pode até pôr-se em contraste radical com estas, mas é imensuravelmente mais forte que a inércia, que o egoísmo, mais forte que a vaidade. Ainda de acordo com Berdiaev

A consciência é mais inexorável que a impassível lei do Estado, e exige bem mais do homem. Assassinamos o nosso próximo não só quando suprimimos a sua vida física com armas de fogo ou de corte. Uma intenção secreta, que nem sempre atinge 
o estado de consciência, direcionada a negar a vida do nosso próximo, é já um assassínio no espírito e o homem é responsável. Todo ódio já é um homicídio [...] quantos movimentos homicidas brotam do profundo da nossa alma, da esfera do subconsciente, quanto frequentemente a nossa vontade é direcionada a diminuir ou suprimir a vida do nosso próximo! [...] A atividade da consciência se faz em Dostoiévski extraordinariamente profunda e aguda, e revela os delitos que fogem de qualquer juízo legal e humano (BERDJAEV, 2002, p.78, tradução nossa).

Mesmo na mais profunda degradação, para a existência humana existe sempre um estreito caminho aberto não mais em direção ao mundo consagrado à morte mas, para além deste, em direção a Deus. Em outras palavras, toda a obra de Dostoiévski gira em torno do problema do homem e do seu destino que, por sua vez, se resolverá na reconciliação do destino do homem com o Deus-homem, Jesus Cristo, através do qual pode ser novamente reestabelecida a imagem original do homem, de modo que "até mesmo no último homem, nas mais terríveis quedas do homem se mantêm a imagem e semelhança de Deus" (BERDJAEV, 2002, p.47, tradução nossa). Ele restitui assim a fé no homem, a qual é a mesma fé em Cristo, no Deus-homem.

A sua fé em Cristo, segundo ele mesmo, passou pelo "cadinho" de todas as dúvidas e se fortaleceu no fogo. Em uma carta escrita à senhora Von Vizin, datada de fevereiro de 1854, encontramos esta belíssima passagem na qual descreve o seu "símbolo da fé":

Este símbolo é muito simples; ei-lo: crer que não existe nada de mais belo, de mais profundo, de mais simpático, de mais razoável, de mais viril e perfeito do que o Cristo. [...] E não basta; se me demonstrassem que Cristo está fora da verdade e efetivamente resultasse que a verdade está fora de Cristo, eu preferirei permanecer com Cristo que com a verdade (DOSTOEVSKIJ, 1951, p.168-169, tradução nossa).

Outro elemento que merece destaque nessa análise é o tema da beleza que ocupa um lugar especial em toda a obra do supracitado autor em seus romances. A beleza, que constitui um enigma, possui um aspecto decisivamente espiritual. No romance O Idiota, o príncipe Mínchkin tem um colóquio com o jovem niilista Hippolit, doente de tuberculose e, por isso, já no fim de sua existência. O jovem lê um documento com o qual denuncia o destino que o proporcionou uma existência infeliz e, como forma de protesto e vingança contra o seu destino, decide pôr fim à própria vida. Mas antes de concretizar esse gesto, que ao final fracassará por um motivo banal - a arma falha -, dirige-se ao príncipe, que o escuta com muita compreensão, com esta pergunta iluminandora: "É verdade, príncipe, que uma vez disseste que o mundo seria salvo pela 'beleza'? Senhores - exclamou, [...] o príncipe sustenta que o mundo será salvo pela beleza. [...] Que tipo de beleza salvará o mundo?" 
(DOSTOEVSKIJ, 1995, p. 518, tradução nossa). O príncipe não responde, permanece em silêncio próximo a ele, não um silêncio mudo, mas cheio de compaixão. Mas se o príncipe Michkin não responde diretamente à pergunta, responde Dostoiévski com a história deste personagem que em sua mente deveria encarnar a figura de Cristo. A salvação para Dostoiévski deveria vir de uma beleza encarnada e vivida no homem e não de uma beleza de tipo meramente estético. Destarte, a encarnação da beleza que salva o mundo é Cristo. Ratificando a intuição de nosso romancista russo, Bento XVI defende que a beleza é atributo do próprio Deus e da sua revelação, com as seguintes palavras:

\begin{abstract}
A revelação cristã, tem uma ligação intrínseca com a beleza: é esplendor da verdade (veritatis splendor). [...] Referimo-nos aqui a este atributo da beleza, vista não enquanto mero esteticismo, mas como modalidade com que a verdade do amor de Deus em Cristo nos alcança, fascina e arrebata, fazendo-nos sair de nós mesmos e atraindo-nos assim para a nossa verdadeira vocação: o amor. [...] No Novo Testamento, realiza-se definitivamente esta epifania de beleza na revelação de Deus em Jesus Cristo: Ele é a manifestação plena da glória divina. [...] Mas, esta beleza não é uma simples harmonia de formas; "o mais belo dos filhos do homem" (Sal 45/44, 3) misteriosamente é também um indivíduo "sem distinção nem beleza que atraia o nosso olhar" (Is 53, 2). Jesus Cristo mostra-nos como a verdade do amor sabe transfigurar inclusive o mistério sombrio da morte na luz radiante da ressurreição. Aqui o esplendor da glória de Deus supera toda a beleza do mundo. A verdadeira beleza é o amor de Deus que nos foi definitivamente revelado no mistério pascal (BENTO XVI, 2007, n 35, p.56-57).
\end{abstract}

Podemos dizer, sem com isso incorrer em extrapolação interpretativa, que a concepção antropológica de Dostoiévski é profundamente cristã, é uma antropodicéia, e que tal concepção faz dele um autêntico escritor cristão uma vez que, no homem e por meio dele, na sua profundidade, se descobre Deus; e assim, para além da dor e do desespero permanece aberta aquela via silenciosa que dá sentido à vida e alivia a morte. Condena-se, na escrita dostoievskiana, a mentira sedutora da divinização do homem proposta pelo niilismo propriamente pela via da liberdade ilimitada aberta a Cristo. E esta sim é uma palavra nova sobre o homem.

\title{
3 A liberdade humana e o problema do mal
}

Para compreender a dinâmica da vida e das ações dos personagens idealizados por Dostoiévski é preciso considerar a liberdade como um princípio fundamental que esses encarnam. É do potencial ilimitado da liberdade do espírito humano que deriva aquilo que em Dostoiévski chamamos pensamento trágico. Se por um lado é através da liberdade que se 
descobre Cristo na profundidade do homem, por outro é Cristo que dá ao homem a liberdade última. Todavia, o homem deve aceitar a Cristo livremente, como nos diz nosso autor por meio das palavras do Grande Inquisidor dirigidas a Cristo em seu famoso romance Os irmãos Kramazov: "não quiseste sujeitar o homem por meio de um milagre, porque desejavas uma fé livre e não inspirada pelo milagre. Tinhas sede de um amor livre, e não dos entusiasmos servis de um escravo aterrorizado diante do potente" (DOSTOEVSKIJ, 2006, p.342-343, tradução nossa). Na livre adesão a Cristo se encontra toda a dignidade do homem, todo o sentido do seu ato de fé, que é um ato de liberdade, no qual está contido o segredo do cristianismo: "a liberdade de fé deles era para Ti mais preciosa que qualquer outra coisa" (DOSTOEVSKIJ, 2006, p. 336, tradução nossa).

São duríssimas as acusações que o Grande Inquisidor faz a Jesus, porém, justamente nessas palavras se pode ouvir a profissão de fé de Dostoiévski, e assim aquilo que deveria ser um tribunal de acusação torna-se um elogio a Jesus:

\begin{abstract}
Em lugar de te apoderares da liberdade humana, tu ainda a estendeste! Esqueceste então de que o homem prefere a paz e até mesmo a morte à liberdade de discernir o bem e o mal? Não há nada de mais sedutor para o homem do que o livre-arbítrio, mas também nada de mais doloroso. E, em lugar de princípios sólidos que teriam tranquilizado para sempre a consciência humana, tu escolheste noções vagas, estranhas, enigmáticas, tudo quanto ultrapassa a força dos homens e com isso agiste como se não os amasses, tu, que vieras dar tua vida por eles! Aumentaste a liberdade humana em vez de confiscá-la e assim impuseste para sempre ao ser moral os pavores dessa liberdade. Querias ser livremente amado, voluntariamente seguido pelos homens fascinados. Em lugar da dura lei antiga, o homem, devia doravante, com coração livre, discernir o bem e o mal, não tendo para se guiar senão tua imagem, mas não previas que ele repeliria afinal e contestaria mesmo tua imagem e tua liberdade, esmagado sob essa carga terrível: a liberdade de escolher? Gritarão por fim que a verdade não estava em ti, de outro modo não os terias deixado numa incerteza tão angustiosa, com tantas preocupações e problemas insolúveis. Preparaste assim a ruína de teu reino. Não acuses ninguém (DOSTOEVSKIJ, 2006, p. 341, tradução nossa).
\end{abstract}

Cristo permanece em silêncio durante todo o poema: a verdade sobre a liberdade é inefável! São colocados em contraste dois princípios universais: a liberdade e a violência, a fé e a incredulidade, o amor divino e a compaixão ateia pelo homem, Cristo e o Anti-Cristo. O Inquisidor argumenta que o caminho da liberdade é por demais difícil, doloroso, e superior às forças de um ser tão mesquinho e insignificante como o homem. E é essa a natureza da sedução do Anti-Cristo, que apresenta de modo refinado e insidioso o mal sempre sob a aparência de bem, que semeia a dúvida e o risco de uma confusão e inversão entre o bem e o mal. O Inquisidor não crê em Deus, mas não crê nem mesmo no homem: perdida a fé em 
Deus não se pode mais crer no homem. O Grande Inquisidor é um insurgente contra Deus em nome de um suposto humanismo sem Deus. Tal revolta contra Deus leva inevitavelmente à negação da liberdade, não restando nada além de um ordenamento terrestre. Mas, como alerta o teólogo e papa emérito Bento XVI, em sua Carta Encíclica Spe Salvi: "se esta liberdade, por causa das condições e das estruturas, lhes fosse tirada, o mundo em última análise não seria bom, porque um mundo sem liberdade não é de forma alguma um mundo bom" (Bento XVI, 2008, $\mathrm{n}^{\mathrm{o}}$ 30, p.40). Assim, uma revolução que teria por base o ateísmo desembocaria fatalmente num despotismo ilimitado. Pela via do arbítrio anticristão e da deificação do homem não se espera nada além de uma inaudita tirania. A obsessão pela ideia de felicidade e igualdade da humanidade sem Deus traz consigo o perigo da destruição da liberdade do espírito humano e consequentemente da ruina do próprio homem.

Observa-se que ao problema da liberdade se vincula o do mal, cuja existência é inexplicável sem a liberdade. De fato, fora dessa relação com a liberdade não existe a responsabilidade pelo mal, e consequentemente o responsável pelo mal seria Deus. Assim, tanto o bem quanto o mal são filhos da mesma liberdade, mas renunciar à liberdade porque esta pode gerar o mal, significaria produzir um mal ainda maior. E qual é a origem do mal? A essa pergunta Dostoiévski responde pela boca do homem do subsolo, para o qual o conhecimento do bem e a prática do mal podem ser contemporâneos, e de fato são; de modo que o fato de conhecer o bem não só não torna impossível a prática do mal, mas pode até mesmo servir de instigação e tentação, pois o mal não é fruto da ignorância, aliás, pode até mesmo ser desejado pelo simples prazer de fazer o mal.

\footnotetext{
Respondam-me o seguinte: por que motivo, nos exatos minutos em que eu era mais capaz de perceber todas as sutilezas "de tudo o que é belo e sublime", como se costumava dizer aqui numa certa época, como que propositalmente eu não as percebia e cometia atos tão indecorosos, atos tais que $[\ldots]$ bem, resumindo, atos que talvez todos pratiquem, mas que, como que de propósito, aconteciam comigo exatamente no momento em que eu mais tinha consciência de que não se deve absolutamente praticá-los? Quanto mais consciência eu tinha do bem e de todo esse "belo e sublime", mais afundava no meu lodo e mais capaz me tornava de atolar-me nele completamente. (DOSTOIÉVSKI, 2002, p. 9, tradução nossa).
}

Ontologicamente pode-se dizer que o mal é nada, não ser, inexistência; torna-se real e existente no momento em que toma emprestado o ser do ser finito. Não por acaso o demônio com quem Ivan Karamazov falava era frequentemente definido como um "parasita". O mal se torna assim uma doença do ser. A sua força é orientada, no seu receptáculo ontológico (o 
homem), a negar nele a presença do absoluto. Assim, a liberdade de quem quer afirmar a si mesmo sem reconhecer nenhuma lei moral, chegando ao ponto de não mais distinguir o bem e o mal, pode transformar-se seja em instinto destrutivo, seja em prazer pela transgressão. E aqui nasce a perversão verdadeira e própria, pela qual se faz o mal não só pela deliberada vontade de infração, mas, mais que isso, pelo prazer de uma consciente e voluntária transgressão, ou seja, fazer o mal pelo mal. E se o mal não fosse mal, se o mal não fosse aquele escândalo que é, não teria sentido chamar em causa nem a liberdade nem tampouco Deus. Desse modo Dostoiévski nos oferece a via para demonstrar a existência de Deus, ou seja, através da afirmação e defesa da liberdade do espírito humano. Aqueles que negam tal liberdade negam também a Deus, e vice-versa. Assim argumenta Berdiaev:

\footnotetext{
Deus, portanto existe, porque existe o mal e a dor no mundo: a existência do mal é uma prova da existência de Deus. Se o mundo fosse exclusivamente bom e justo, então Deus não seria mais necessário, então o mundo seria Deus. Deus existe porque existe o mal. Isto significa que Deus existe, enquanto existe a liberdade (BERDJAEV, 2002, p.66, tradução nossa).
}

A originalidade de Dostoiévski consiste na sua convicção de que sem a experiência da liberdade e sem a experiência do mal, a harmonia universal não pode ser aceita. No mundo existe tanto mal e tanta dor porque na base do mundo está a liberdade; e na liberdade se encontra toda a dignidade do homem e do mundo. Sem a liberdade o mundo seria necessariamente bom e feliz, mas se privaria do seu caráter divino, porque este caráter é, sobretudo, liberdade, qual mistério último da criação.

A liberdade é, por assim dizer, o marco fundante para compreender a concepção de homem em Dostoiévski. Ele nos permite compreender que a liberdade não é exclusivamente uma faculdade da alma, ou seja, aquela de optar pelo bem e rejeitar o mal, e nem é tão somente um valor - embora seja o mais elevado e sacrossanto de todos -, mas representa algo de mais originário que vai colhido num plano metafísico antes mesmo que no psicológico, isto é, no mais profundo do ser. No entanto, é preciso entender que a liberdade é instrumento tanto do bem como do mal sem, contudo, esquecer que, para Dostoievski, não existe bem senão enquanto fruto de uma escolha livre e consciente e que na ausência desta qualquer bem se transformaria imediatamente no seu contrário. Tal é o fim de uma justiça imposta com a força, ou de um sacrifício ao qual se é obrigado e, até mesmo, do mandamento que impõe de amar o próximo, quando é diminuída a liberdade. Esse princípio é ilustrado por Bento XVI: 


\begin{abstract}
Visto que o homem permanece sempre livre, e dado que a sua liberdade é também sempre frágil, não existirá jamais neste mundo o reino do bem definitivamente consolidado. Quem prometesse o mundo melhor que duraria irrevogavelmente para sempre faria uma promessa falsa; ignora a liberdade humana. A liberdade deve ser incessantemente conquistada para o bem. A livre adesão ao bem nunca acontece simplesmente por si mesma. Se houvesse estruturas que fixassem de modo irrevogável uma determinada - boa - condição do mundo, ficaria negada a liberdade do homem e, por este motivo, não seria de modo algum, em definitivo, boas estruturas (BENTO XVI, 2008, no 24, p.36).
\end{abstract}

O bem e o mal só são o que são enquanto relacionados à liberdade, de modo que a liberdade é anterior ao bem e ao mal, ou seja, anterior à distinção que se dá pelo fato que o bem é bem e o mal é mal só se acolhidos livremente. Assim, um bem que não seja livre não é um bem mas um mal, enquanto um bem que seja verdadeiramente bem e, portanto, livre, pressupõe a liberdade para o mal. É realmente difícil, num primeiro contato com a obra de Dostoiévski a partir de sua hipótese clássica sobre a liberdade, o sofrimento e o mal, não deduzir dessa uma espécie de exaltação ao sofrimento, um sofrer pelo sofrer. Na verdade, o sofrimento parece ser o caminho para a redenção do homem, isso se dá porque esta é a condição ontológica do ser humano e não por apologia à dor e ao sofrimento. De fato, no mundo existe o mal e o sofrimento porque existe a liberdade. Somente nessa perspectiva se pode compreender a "crueldade" de Dostoiévski, que não quer de modo algum livrar o homem da dor e do sofrimento ao preço de privá-lo da sua liberdade, como nos alerta Pondé quando afirma que "a salvação passa pelo sofrimento e pelo sacrifício. Não há redenção sem dor, sem sofrimento, sem agonia; quem nega essa agonia, seja lá por que razão for, é um mentiroso, seja no plano do conhecimento, da moral, ou psicológico" (PONDÉ, 2013, p.185).

Se não existisse a liberdade o mundo e os seus horrores seriam pura absurdidade, nem mesmo Deus poderia ser aceito. E aqui se encontra a absoluta originalidade da liberdade, qual seja: pode tanto resgatar o ser do nada quanto precipitá-lo no nada. Por isso a opção fundamental pelo bem ou pelo mal cabe a cada homem, o qual é interpelado a responder se a vida, não só a sua, mas a de todos, seja digna de ser vivida ou apenas uma grande absurdidade.

O homem se encontra, então, diante de uma alternativa paradoxal: de uma parte o ateísmo que nasce como contestação a Deus pela impossibilidade de conciliar a sua existência com a existência do mal, o mesmo ateísmo que reivindica a liberdade do homem, mas que na realidade não sabe o que fazer com esta liberdade e por isso a teme; da outra parte o cristianismo, que não conhece Deus senão por meio do mal e do sofrimento, conforme sugere Sergio Givone: 
Dostoiévski leva decisivamente o ateísmo para dentro da fé e depois de ter negado, ateísticamente, Deus, pela base do reconhecimento da irredutível escandalosidade do mal, identifica Deus com este mesmo escândalo: porque, paradoxalmente, somente diante de Deus que mal é escandaloso, escandaloso ao ponto de curvar o divino a um absoluto sofrer (GIVONE, 2006, p.163, tradução nossa).

Dostoiévski assumiu profundamente a revolta contra uma ordem conquistada pelo preço de sofrimentos desumanos, todavia, acreditava não só na compaixão, mas também na paixão, na força expiadora do sofrimento. Assim é possível compreender como o próprio Deus, ao invés de se contentar em dar as razões do sofrimento, silencia ao ponto de identificar-se com ele. Eis o único sentido possível do sofrimento: padecido e compadecido por Deus torna-se lugar de redenção e libertação. Em sintonia com essa abordagem de Dsotoiévski são iluminadoras as palavras de Bento XVI sobre o sentido do sofrimento:

\footnotetext{
Cristo desceu aos "infernos" ficando assim perto de quem é lançado nele, transformando para ele as trevas em luz. O sofrimento, os tormentos continuam terríveis e quase insuportáveis. Surgiu, porém, a estrela da esperança - a âncora do coração chega até o trono de Deus. Não se desencadeia o mal no homem, mas vence a luz: o sofrimento - sem deixar de o ser - torna-se, apesar de tudo, canto de louvor (BENTO XVI, 2008, $\mathrm{n}^{\circ} 37, \mathrm{p} .48$ ).
}

Assim, nessa experiência onde a dor e o sofrimento são uma inevitável consequência da liberdade, o verdadeiro vértice do cristianismo dostoievskiano enquanto condição universal cujo cumprimento o homem está a caminho, em direção a um amor transfigurante do sofrimento e da dor, encontra em Cristo a sua consumação última.

\section{A superação do niilismo}

Dentre os autores contemporâneos a Dostoiévski faz-se frequentemente referência a Friedrich Nietzsche que, como o romancista russo, possuía uma percepção trágica sobre a existência humana, porém, muito profundamente ligado à cultura grega e substancialmente estranho ao cristianismo e, por isso, incapaz de entrever na figura salvífica de Cristo o resgate da humanidade. No filósofo alemão essa tragicidade da existência humana se resolveria no niilismo.

A palavra de Nietzsche sobre a superação da ética, de tal modo fascinante e radical, pareceu ser última e definitiva a ponto de fechar o discurso sobre a dimensão essencialmente 
moral da existência humana. Mas antes mesmo de Nietzsche, e como se tivesse evocado sua presença, Dostoiévski, que nada sabia sobre o filósofo alemão, demonstrou como a pretensão de ultrapassar a ética, e consequentemente ultrapassar o homem, acaba por precipitar novamente o homem no lugar que lhe é mais próprio: na via da liberdade, na luta entre o bem e o mal. A concepção de Dostoiévski é trágica, mas na medida em que o fardo da liberdade pesa inteiramente sobre o homem conferindo-lhe toda a sua dignidade. Pondé enfatiza:

É nesse sentido, portanto, que Dostoiévski afirma que os ateus não percebem que a morte não é a principal forma de decomposição, pois esta já aconteceu em vida. E o ateísmo nada mais é do que a aposta na decomposição do indivíduo vivo. Daí sua concepção do ateísmo como a maior tragédia existente no mundo. O niilismo é seu nome conceitual (PONDÉ, 2013, p.91).

Muito embora seja frequentemente associada ao pensamento nietzschiano, a descoberta da ideia de super-homem, do homem-deus, pertence indiscutivelmente a Dostoiévski. Ele colhe perfeitamente em seus romances a lógica do niilismo que não é apenas ateísta, mas rigorosamente antiteísta. Segundo René Girard, a ideia de fundo dos romances dostoiévskianos é a de que "o niilismo é a fonte de todas as ideologias, porque é a fonte de todas as divisões e de todas as oposições subterrâneas”. (GIRARD, 2005, p.80). A sua dialética é fundada na oposição Deus-homem e homem-deus, Cristo e Anticristo, e o problema do destino humano é colocado ao interno dessa oposição. Esta intuição dostoievskiana alcança, por sua vez, uma particular intensidade na figura de Kirilov, personagem chave de Os Demônios, que apresenta ao narrador anônimo a sua ideia focada no anúncio do "homem novo":

\footnotetext{
A vida é dor, a vida é medo, o homem é um infeliz. Hoje tudo é dor e medo. Hoje o homem ama a vida porque ama a dor e o medo. E foi assim que fizeram. Agora a vida se representa como dor e medo, e nisso está todo o engano. Hoje o homem ainda não é aquele que deve ser. Haverá um novo homem, feliz e orgulhoso. Aquele para quem for indiferente viver ou não viver será o novo homem. Quem vencer a dor e o medo, esse mesmo será Deus. E o outro Deus não existirá. [...] Deus é a dor do medo da morte. Quem vencer a dor e o medo se tornará Deus. Então haverá uma nova vida, então haverá um novo homem, tudo novo... Então a história será dividida em duas partes: do gorila à destruição de Deus e da destruição de Deus... [...] À mudança física da terra e do homem. O homem será Deus e mudará fisicamente. O mundo mudará, e as coisas mudarão, e mudarão os pensamentos e todos os sentimentos. [...] Aquele que desejar a liberdade essencial deve atrever-se a matarse. Aquele que se atreve a matar-se terá descoberto o segredo do engano. Além disso não há liberdade; Nisso está tudo, além disso não há nada. Aquele que se atrever a matar-se será Deus. Hoje qualquer um pode fazê-lo por que não haverá Deus nem haverá nada. [...] Aquele que se matar apenas para matar o medo imediatamente se tornará Deus. (DOSTOEVSKIJ, 1994, p.106-107, tradução nossa).
} 
Kirilov espera não uma vida eterna futura, mas uma vida eterna presente. Deseja salvar o homem dando-lhe imortalidade através de uma humanidade divinizada, do homemdeus. Para tanto, com um ato de livre-arbítrio se oferece como vítima e se suicida, porém, essa não é a morte na cruz que traz a salvação; é em tudo oposta à morte de Cristo. O itinerário de Cristo procede por meio da Cruz em direção à Ressurreição, em direção à vitória sobre a morte; o itinerário de Kirilov, ao contrário, termina com a morte e ignora a Ressurreição. Kirilov pretende tornar-se ele mesmo um Deus, pois permanecer apenas homem não lhe é mais suficiente nem possível. Nas vicissitudes desse personagem Dostoiévski mostra que a ideia da divinização do homem, a ideia do homem-deus leva consequentemente a uma destruição interior do próprio homem. Assim, a sua obra representa não só uma crise, mas, também o colapso do velho humanismo racionalista, como destaca Pondé em sua análise sobre o caráter "horizontalista" da modernidade quando afirma que "uma religião humanista é uma religião que prega o homem no lugar de Deus, e horizontalidade é degradação; logo, uma religião como essa só pode implicar em investimento na ideia de uma eternidade podre" (PONDÉ, 2013, p.208-209).

Em Dostoiévski Deus e o homem permanecem até o fim. No homem-deus o homem perece, mas no Deus-homem o homem se salva. Somente o cristianismo salva a ideia de homem, conservando a sua imagem. Em Deus o homem nunca desaparece, porém a morte de Deus implica a morte do homem. Eis porque, para Dostoiévski, dentre todos os problemas aquele central e decisivo é o problema de Deus, e é o próprio niilismo que o evidencia no momento em que tenta negá-lo. Pensar o niilismo em sua profundidade pressupõe levar a sério todas essas instigantes provocações que Dostoiévski nos faz ouvir através da polifonia de seus personagens.

\section{Considerações finais}

A presenta análise não pretendeu exaurir a riqueza e o alcance da obra dostoievskiana. Contudo, não obstante nossas limitações, apresentamos, mesmo que sucintamente, um ensaio filosófico sobre temas de antropologia filosófica e filosofia da religião presentes em romances de Dostoievski, recorrendo para tanto, com frequência, a pesquisas realizadas até agora por alguns de seus principais estudiosos. E, mesmo não podendo afirmar que Dostoiévski tenha resolvido todos os problemas por ele colocados, que reconhecidamente constituem os grandes problemas não só da filosofia, mas da humanidade até nossos dias - Deus, o homem, a 
liberdade, o mal -, podemos, todavia, reconhecer a sua grande contribuição para a pesquisa filosófico-antropológica, que marcou profundamente a concepção sobre o homem do século XX em diante. Dostoiévski foi um verdadeiro artista, um magnífico pintor dos "movimentos subterrâneos" da natureza humana. Impossível ler os seus romances e permanecer indiferentes à tragicidade da vida humana narrada nos trágicos eventos vivenciados por seus personagens. O contato profundo com a sua arte nos contagia do começo ao fim e constitui um acontecimento único na vida.

Mesmo não podendo considerar Dostoiévski um filósofo no sentido rigoroso do termo, isto é, alguém que tenha construído um edifício filosófico bem sistematizado, ele foi, no entanto, um autêntico filósofo no sentido lato, como atesta Berdiaev: "Dostoiévski não foi apenas um grande artista, mas também um grande pensador e um grande visionário. É um dialético de gênio, o maior metafísico russo" (BERDJAEV, 2002, p.5, tradução nossa). Pois, é com o modo de ser e de agir, antes mesmo que com o desenvolvimento pontual de argumentações teóricas, que os personagens dostoievskianos suscitam problemas e tentam resolvê-los. Algo que também merece destaque na arte de Dostoiévski é o fato de suas ideias versarem sobre o concreto, distantes das concepções abstratas. Tal caráter concreto, vital e cotidiano das ideias adquirem vida em seus personagens.

Não obstante a sua reconhecida capacidade de ler e compreender a sutileza da alma humana, alguém poderia objetar que talvez não se devesse propor a dor, o sofrimento, a tragédia, como itinerário processual da vida. Para alguns, quem sabe, Dostoiévski não tenha sido um exímio mestre da liberdade, embora tenha reconhecido a liberdade como fundamento radical da vida humana. Para o romancista russo, de fato, a tragédia, o abismo, a dor e o sofrimento permanecem como o único caminho para o homem, o caminho por excelência, pois a via que conduz à luz passa necessariamente pelas trevas. Provavelmente a grandeza de Dostoiévski esteja justamente em ter demonstrado como nas trevas possa resplandecer a luz, característica peculiar de sua obra. Ele ligou dialeticamente dois abismos inconciliáveis, niilismo e religião, ao ponto de se afirmar que um é verdadeiramente o que é apenas no espelho do outro. E neste ponto ele permanece para nós um excelente mestre, porque nos desafia a descobrir a luz nas trevas através de Cristo, a reconhecer a imagem e semelhança de Deus no homem mais desprezível, ensina o amor pelo homem unido ao respeito por sua liberdade. Mesmo nos conduzindo através das trevas não é a elas que pertencem a sua última palavra. Se existe uma ideia que a sua obra não tem a menor intenção de propor é a de um 
pessimismo obscuro sem porta de saída, pois crê firmemente que a luz de Cristo, que penetra e vence o mundo, ilumina todas as trevas.

E, por fim, podemos acrescentar um último aspecto não menos importante de seu legado: embora tenha sido um crítico ferrenho do cristianismo ocidental em suas versões católica e protestante, estava convencido de sua força renovadora. É no interior do próprio cristianismo, e não fora, que deve ocorrer um renascimento, uma renovação do espírito humano. Neste sentido, e em última análise, a obra de Dostoiévski foi e continua sendo profundamente fecunda e inspiradora para uma necessária e contínua renovação cristã.

\section{Referências}

BENTO XVI, Papa. Carta Encíclica Spe salvi: sobre a esperança cristã. 2. ed. São Paulo: Loyola, 2008.

BENTO XVI, Papa. Exortação Apostólica Pós-Sinodal Sacramentum Caritatis: sobre a Eucaristia, fonte e ápice da vida e da missão da Igreja. 2. ed. São Paulo: Paulinas, 2007.

DOSTOEVSKIJ. Fëdor. I fratelli Karamazov. Traduzione di Pina Maiani e Laura Satta Boschian. Milano: Rizzoli, 2006.

DOSTOEVSKIJ. Fëdor. Memorie del sottosuolo. Traduzione di Alfredo Polledro. Torino: Einaudi, 2002.

DOSTOEVSKIJ. Fëdor. L'idiota. Traduzione di Eugenia Maini ed Elena Mantelli. Milano: Mondadori, 1995.

DOSTOEVSKIJ. Fëdor. I demonî. Traduzione di Alfredo Polledro. Torino: Einaudi, 1994.

DOSTOEVSKIJ. Fëdor. Epistolario. Napoli: Edizioni Scientifiche Italiane, 1951.

BERDJAEV, Nikolaj. La concezione di Dostoevskij. Traduzione di Bruno Del Re. 3. ed. Torino: Einaudi, 2002. (Coll. Piccola Biblioteca Einaudi 161, Nuova serie, Saggistica letteraria e linguistica).

GIRARD, René. Dostoevskij: dal doppio all'unità. Traduzione di Roberto Rossi. Milano: SE, 2005.

GIVONE, Sergio. Dostoevskij e la filosofia. 2. ed. Bari: Laterza, 2006. (Coll. Biblioteca Universale Laterza 586).

PAREYSON, Luigi. Dostoiévski: filosofia, romance e experiência religiosa. Tradução de Maria Helena Nery Garcez e Sylvia Mendes Carneiro. São Paulo: EDUSP, 2012.

PONDÉ, Luiz Felipe. Crítica e profecia: a filosofia da religião em Dostoiévski. São Paulo: LeYa, 2013. 